\title{
Prevalence and Transmission of SARS-CoV-2 in Childcare Facilities: A Longitudinal Study
}

Luise Haag ${ }^{1, *}$, Judith Blankenburg ${ }^{1, *}$, Manja Unrath $^{1}$, Johanna Grabietz ${ }^{1}$, Elisabeth Kahre ${ }^{1}$, MD, Lukas Galow ${ }^{1}$, MD, Josephine Schneider ${ }^{1}$, Alexander H. Dalpke ${ }^{2}$, MD, Christian Lück ${ }^{2}$, MD, Leo Büttner ${ }^{2}, \mathrm{MD}$, Reinhard Berner ${ }^{1}, \mathrm{MD}$, Jakob P. Armann ${ }^{1}$, MD

* Contributed equally as co-first authors

Affiliations: ${ }^{1}$ Department of Pediatrics, University Hospital and Medical Faculty Carl Gustav Carus, Technische Universität Dresden, Fetscherstrasse 74, 01307 Dresden, Germany;

${ }^{2}$ Institute for Medical Microbiology and Virology, Medical Faculty Carl Gustav Carus, Technische Universität Dresden

\section{Short title: KiTaCoviDD19-study: SARS-CoV-2 in Childcare Centers}

Corresponding Author: Jakob P. Armann, Department of Pediatrics, University Hospital and Medical Faculty Carl Gustav Carus, Technische Universität Dresden, Fetscherstrasse 74, 01307 Dresden, Germany; email: jakob.armann@uniklinikum-dresden.de; telephone: +49 351 45818568

Conflict of Interest Disclosure: Alexander H. Dalpke, Reinhard Berner and Jakob P. Armann report grants from the Federal State of Saxony during the conduct of the study. The other authors have no conflicts of interest to disclose.

Funding: This study was supported by a grant by the Federal State of Saxony.

Role of the Funding Source: The funder of the study had no role in the study design, data collection, data analysis, data interpretation, or writing of the report.

Clinical Trial Registration: KiTaCoviDD19: SARS-CoV-2 Surveillance im Vorschulalter (COVID-19), DRKS00022729, https://www.drks.de/drks_web/navigate.do?navigationId=trial.HTML\&TRIAL_ID=DRKS00 022729

Data Sharing: Deidentified individual participant data (including data dictionaries) will be made available, in addition to study protocols, the statistical analysis plan, and the informed consent form. The data will be made available upon publication to researchers who provide a methodologically sound proposal for use in achieving the goals of the approved proposal. Proposals should be submitted to jakob.armann@uniklinikum-dresden.de

\section{Abbreviations:}

COVID-19 Coronavirus disease 2019

ELISA enzyme-linked immunosorbent assay

IgG Immunoglobulin G

IQR Interquartile Range

PCR Polymerase Chain Reaction

SARS-CoV-2 severe acute respiratory syndrome coronavirus type 2 


\section{Table of Contents Summary:}

This longitudinal study among children, parents and childcare workers provides further insight on SARS-CoV-2 prevalence and transmission within childcare facilities.

\section{What's Known on This Subject:}

Based on age distribution of SARS-CoV-2 infections and previous data of very limited spread of COVID-19 among primary and secondary schools there is reason to believe that children play a less crucial role in SARS-CoV-2 transmission than initially assumed.

\section{What This Study Adds:}

Previously published studies focus mainly on SARS-CoV-2 transmission in schools. This longitudinal study provides information on prevalence, transmission and spread of SARSCoV-2 within childcare facilities during low- and high-prevalence settings.

\section{Contributors' Statement:}

Dr Armann conceptualized and designed the study, wrote the protocol, collected samples, analyzed and verified the data, drafted the initial manuscript, and reviewed and revised the manuscript.

Ms Haag and Ms Blankenburg collected samples, analyzed and verified the data, drafted the initial manuscript, and reviewed and revised the manuscript.

Prof Berner conceptualized and designed the study, wrote the protocol, and reviewed and revised the manuscript.

Prof Dalpke conceptualized and designed the study, wrote the protocol, performed laboratory analyses, and reviewed and revised the manuscript.

Drs Lück and Büttner performed laboratory analyses, and reviewed and revised the manuscript.

Dr Galow and Ms Unrath conceptualized and designed the study, wrote the protocol, collected samples, and reviewed and revised the manuscript.

Dr Kahre, Ms Schneider and Ms Grabietz collected samples, and reviewed and revised the manuscript.

All authors approved the final manuscript as submitted and agree to be accountable for all aspects of the work. 


\begin{abstract}
Objectives

Previous data indicate that children might play a less crucial role in SARS-CoV-2

transmission than initially assumed. We conducted a study to gain further knowledge on prevalence, transmission and spread of SARS-CoV-2 among preschool children, their parents and caretakers.
\end{abstract}

\title{
Methods
}

Children, their parents and care givers in 14 childcare facilities in Dresden, Saxony/ Germany were invited to participate in the KiTaCoviDD19-study between July 2020 and January 2021. Seroprevalence of SARS-CoV-2 antibodies was assessed up to 4 times during the study period in all participating adults and personal characteristics as well as epidemiological information of personal SARS-CoV-2 history were obtained. Stool viral shedding of SARSCoV-2 was analyzed every 2-4 weeks in all participating children.

\section{Results}

In total, 318 children, 299 parents and 233 childcare workers were enrolled. The percentage of seropositive adults and SARS-CoV-2 positive detected children rose considerably by January 2021. However, the rate of SARS-CoV-2 positive children was considerably lower than the rate of seropositive adults. Overall, we detected a maximum of three connected cases in children. About $50 \%$ of SARS-CoV-2 infections in children could not be connected to a secondary case within our study population.

\section{Conclusion}

The study could not provide evidence for a relevant asymptomatic ("silent") spread of SARSCoV-2 in childcare facilities, neither in a low nor a high prevalence setting. This finding adds to the evidence that childcare and educational settings do not play a crucial role in driving the SARS-CoV-2 pandemic. 


\section{Introduction}

Since the Beginning of COVID-19 pandemic ${ }^{1}$ school and childcare closures are one of the main strategies to limit transmission. These measures are based on the assumption that children play a similar role in transmitting SARS-CoV-2 as they do in transmitting influenza and that schools and childcare facilities closures effectively lower the overall transmission rate $^{2}$

However, most countries, including Germany, report a much lower proportion of cases in children compared to their population size ${ }^{3-5}$. In addition, COVID-19 mostly leads to no or mild symptoms in children and presents a low risk of a serious course of disease to children, whereas the impact of school closures and limited social interactions on children's mental health is becoming increasingly apparent ${ }^{6,7}$.

While several studies in the UK and Norway could only identify a very limited spread of COVID-19 in primary and secondary schools ${ }^{8,9}$ similar studies in preschools and childcare facilitis are lacking so far. Given the difficulty of implementing relevant distancing and hygiene meassures in this age group SARS-CoV-2 transmission in childcare facilities are of particular interest.

This study ivestigates SARS-CoV-2 transmission in childcare facilities attended by children between 1 and 6 years of age.

Mitigation strategies implemented by the Federal State of Saxony included a mask mandate for parents and limited access during drop-off and pick-up times. There was no recommendation for childcare workers or children to wear masks. Starting on December $14^{\text {th }}$, childcare facilities limited their service to emergency care for children of essential workers. Individuals with a confirmed SARS-CoV infection, close contact to an infected individual or 
individuals with respiratory symptoms with or without fever were not allowed to attend daycare facilities during the study period

\section{Methods}

\section{$\underline{\text { Study Design }}$}

Children, their parents and childcare workers in 14 childcare facilities in Dresden, Saxony/ Germany were invited to participate in the KiTaCoviDD19-study.

After informed consent, $5 \mathrm{~mL}$ of peripheral venous blood were collected from adult participants and serological testing for IgG-antibodies against SARS-CoV-2 was conducted. Parents were asked to collect stool samples from their children every two weeks. Excretion of SARS-CoV2, as mostly non-infectious particle, is known to occur in infected people, especially children, for at least two weeks ${ }^{10}$. This was used as an easy-to-obtain specimen in the childcare population. These stool samples were tested by PCR to detect stool excretion of SARS-CoV-2 RNA. All blood and stool samples were collected between July 2020 and January 2021.

In addition, data on age, household size, comorbidities, regular medication and previously diagnosed SARS-CoV-2 infections in participants or their household contacts quarantine episodes, utilization of daycare during lockdown, number of contacts other than householdcontacts and the occurrence of respiratory symptoms were collected.

\section{$\underline{\text { Laboratory Analysis }}$}

Stool samples were frozen at $-80^{\circ} \mathrm{C}$ and were thawed earliest after 4 weeks of storage. According to study protocol, initially, every second stool sample was examined. If at least one 
medRxiv preprint doi: https://doi.org/10.1101/2021.04.16.21255616; this version posted April 18, 2021. The copyright holder for this preprint (which was not certified by peer review) is the author/funder, who has granted medRxiv a license to display the preprint in perpetuity.

It is made available under a CC-BY-NC-ND 4.0 International license .

stool sample within one childcare facility tested positive, all samples from this institution collected two weeks earlier and later were tested as well.

The liquid handling system MicroLab Nimbus (Seegene, Duesseldorf, Germany) was used for nucleic acid extraction using a modified protocol supplied by the manufacturer (spatula point of stool in 1 $\mathrm{ml}$ of ASL buffer, Qiagen/ mixed thoroughly and incubated for at least 10min/ centrifuged at $16.060 \mathrm{~g}$ for $2 \mathrm{~min} /$ supernatant was used for extraction procedure) as well as for PCR setup. Extraction was followed by real time reverse transcriptase polymerase chain reaction (RT-PCR) using Seegene's Allplex ${ }^{\mathrm{TM}} 2019-\mathrm{nCoV}$ assay. This assay detects three target regions within the genome of SARS-CoV-2, namely the E gene, RdRP gene and N gene. The automatic calculation software supplied by Seegene was used for interpretation of the results. A specimen was considered positive in case of at least one detected target region. In each test series a stool specimen from a patient with confirmed SARS-CoV-2 infection was run in parallel as a positive control for correct extraction and PCR procedure. In case of test inhibition (internal control) the assay was repeated once.

Blood samples were assessed for SARS-CoV-2 IgG antibodies using a commercially available chemiluminescence immunoassay (CLIA) technology for the quantitative determination of anti-S1 and anti-S2 specific IgG antibodies to SARS-CoV-2 (Diasorin LIAISON® SARS-CoV-2 S1/S2 IgG Assay). Antibody levels > 15.0 AU/ml were considered positive and levels between 12.0 and $15.0 \mathrm{AU} / \mathrm{ml}$ were considered equivocal.

All samples with a positive or equivocal LIAISON® test result, as well as all samples from participants with a PCR-confirmed SARS-CoV-2 infection, were tested with two additional serological tests (chemiluminescent microparticle immunoassay (CMIA) intended for the qualitative detection of IgG antibodies to the nucleocapsid protein of SARS-CoV-2 (Abbott Diagnostics ${ }^{\circledR}$ ARCHITECT SARS-CoV-2 IgG ) and an ELISA detecting IgG against the S1 domain of the SARS-CoV-2 spike protein (Euroimmun ${ }^{\circledR}$ Anti-SARS-CoV-2 ELISA)). 


\section{Definitions}

Participants with detectable antibodies in at least two assays were considered seropositive. The study period was divided into a low-prevalence phase (July $15^{\text {th }}, 2020-$ November $15^{\text {th }}$, 2020) in which cumulative reported cases tripled in Dresden and a high-prevalence phase (November $16^{\text {th }}, 2020$ - January $31^{\text {st }}, 2021$ ) in which cumulative cases increased more than 10-fold (figure 1). Only children with at least two donated stool samples in the respectively defined periods were included in the analysis. 232 out of 318 children $(73.0 \%)$ met these criteria in the low prevalence phase and 222 out of 318 children $(69.8 \%)$ in the high prevalence phase (table 1). No positive stool sample was excluded by these criteria.

Cases within one facility were considered as possibly linked if there was an epidemiological and temporal association. Epidemiological association was defined as at least two SARSCoV-2 infections within the same institution. Temporal association was defined as cases occurring within the infectious period of each other. This period is defined as 48 hours before onset of symptoms or positive PCR-test until 14 days after onset of symptoms. For stool samples we extended this period to 14 days before and after the positive sample was collected. In cases of consecutive positive samples, only the date of the first positive stool sample was taken into consideration as previous studies have shown that SARS-CoV-2 RNA can be shed through stool for multiple weeks whereas the infectious period is usually limited to the first 10 days ${ }^{11}$.

\section{Statistical Analysis}


Analyses were performed using IBM SPSS 25.0 and Microsoft Excel 2010. Fisher's exact test was used to determine categorical variables for the statistical analysis. P-values $\leq 0.05$ were defined as statistically significant.

\section{Approval}

The KitaCoviDD19-study which was approved by the Ethics Committee of the Technische Universität (TU) Dresden (BO-EK-180052020), registered on July $15^{\text {th }}, 2020$ and assigned the clinical trial number DRKS00022729.

\section{Results}

\section{Study population/ Demographics}

318 children, 299 parents and 233 childcare workers in 14 childcare facilities were enrolled representing $72 \%(50-100 \%)$ of all staff members and 18\% (12-27\%) of children attending these institutions (table 1). For 314 out of 318 children (99\%) corresponding parental serostatus was available. $38(12 \%)$ were siblings.

The median age of the children was 4 (IQR 2-5), their parents 37 (IQR 34-40) and childcare workers 39 (IQR 32-49). The median household size for children and parents was 4 (IQR 3-4) and 3 (IQR 2-3) for the participating childcare workers. (table 2.)

\section{Low-prevalence period}

At baseline, none of the participants were SARS-CoV-2 seropositive. In the low-prevalence phase until mid-November 2 study participants, one childcare worker $(1 / 154-0.7 \%)$ and one 
parent $(1 / 196-0.5 \%)$ became seropositive. Both participants reported a known PCRconfirmed infection. They did not attend the same childcare facility.

During the same period, we detected 2 positive stool samples, resulting in a cumulative prevalence of 2 out of 232 children ( $0.9 \%$ ) SARS-CoV-2 positive children (table 3). These children attended different childcare facilities. One case was not previously detected, however there was no epidemiological linked case in the same institution. The other child was symptomatic and SARS-CoV-2 infection was detected by PCR at that time. One epidemiological linked case occurred in the same institution. In both cases, the parents did not have detectable antibodies, nor did they report positive PCR-testing for SARS-CoV-2.

\section{High-prevalence period}

At the end of January 2021 - after the second wave of the pandemic - 25 out of $236(10.6 \%)$ parents and 23 out of 187 (12.3\%) childcare workers were seropositive (table 3). The difference between the two groups showed no statistical significance $(\mathrm{p}=0.64)$.

Seroprevalence in parents whose children remained in emergency care during the strict lockdown was significantly higher (12/64 (18.8\%)) than parents whose children did not visit the facility during this time $(13 / 152(8.6 \%) ; \mathrm{p}=0.038)$. Seroprevalence in childcare workers assigned mainly administrative was significantly higher $(10 / 48(20.8 \%))$ than those with mainly childcare related duties $(8 / 99(8.1 \%) \mathrm{p}=0.034$

Eleven seropositive participants ( 2 childcare workers and 9 parents) had an additional serum sample taken mid-December. Three out of $11(27.3 \%)$ were already seropositive at this time while 8 out of $11(72.7 \%)$ seroconverted during the strict lockdown starting December $14^{\text {th }}$, 2020. 
medRxiv preprint doi: https://doi.org/10.1101/2021.04.16.21255616; this version posted April 18, 2021. The copyright holder for this preprint (which was not certified by peer review) is the author/funder, who has granted medRxiv a license to display the preprint in perpetuity.

It is made available under a CC-BY-NC-ND 4.0 International license .

A total of 68 out of 187 childcare workers (36.4\%) and 93 out of 236 parents (39.4\%) reported symptoms of an upper respiratory tract infection during the study period.

\section{Seropositive parents and childcare workers}

20 out of 25 seropositive parents $(80.0 \%)$ had been previously tested positive for SARS-CoV2 and one reported a confirmed SARS-CoV-2 positive household member. Similarly, 18 out of 23 childcare workers (78.3\%) had a personal SARS-CoV-2 history, and one childcare worker had a respective household history. The ratio of undetected to detected SARS-CoV-2 infections did not differ significantly between parents (4/21 (0.19)) and childcare workers $(4 / 19(0.21))$.

Ten out of 25 seropositive parents $(40.0 \%)$ and 5 out of 23 seropositive childcare workers (21.7\%) named a confirmed SARS-CoV-2 contact outside the childcare facility as source of infection.

\section{SARS-CoV-2 positive children}

During the second study period 15 out of 222 children (6.8\%) had at least one SARS-CoV-2 positive stool sample. These cases occurred in 8 different institutions. In 4 childcare facilities a possible epidemiological link between a maximum of 3 children each could be identified. In the remaining 6 of 14 cases there was no connection to other children with SARS-CoV-2 positive stool samples.

Altogether, SARS-CoV-2 RNA was detected in a total of 22 out of 1168 analysed stool samples, belonging to 17 different children. 5 out of 17 children had two consecutive positive samples. In 8 out of 17 (47\%) cases a personal or household contact PCR-confirmed SARS- 
medRxiv preprint doi: https://doi.org/10.1101/2021.04.16.21255616; this version posted April 18, 2021. The copyright holder for this preprint (which was not certified by peer review) is the author/funder, who has granted medRxiv a license to display the preprint in perpetuity.

It is made available under a CC-BY-NC-ND 4.0 International license .

CoV-2 infection was reported, leading to a ratio of $1.125(9: 8)$ of undetected to detected SARS-CoV-2 infections in the participating children.

64 out of 219 parents $(29.2 \%)$ reported that their children visited the childcare facility during the strict lockdown starting on December $14^{\text {th }}, 2020$. Cumulative SARS-CoV-2 prevalence was not significantly between children attending emergency care and those who did not (4/64 $(6.3 \%)$ vs $13 / 152(8.6 \%) ; \mathrm{p}=0.78)$.

\section{$\underline{\text { SARS-CoV-2 transmission in childcare facilities }}$}

The 17 SARS-CoV-2 positive children attended 8 different childcare facilities, in the remaining 6 facilities no positive stool samples were detected. The maximum number of children with a SARS-CoV-2 positive stool sample per center was 4.2 out of 17 children with stool viral shedding had siblings who were enrolled in this study as well. In both cases the stool samples of the respective sibling yielded negative results. 5 out of 17 children $(29.4 \%)$ did not visit the childcare center prior to or during their viral shedding, thereby eliminating the possibility of an infection connected to their childcare center.

Six out of 17 parents $(35.3 \%)$ with a SARS-CoV-2 infected child were seropositive, 3 parents did not undergo serological testing after their children's positive stool sample and 8 out of 17 (47.1\%) were seronegative.

12 of the 17 children with a SARS-CoV-2-positive stool sample attended their childcare facility at the time of viral shedding. This affected 5 institutions. In 7 cases at 4 institutions at least one epidemiologically associated SARS-CoV-2 case could be detected. In 5 out of 12 cases there was no epidemiological associated SARS-CoV-2 case within the same facility.

Regarding the occurrence of epidemiological linked transmissions within the participating institutions we detected at least one SARS-CoV-2 positive participant in 13 out of 14 (92.8\%) 
medRxiv preprint doi: https://doi.org/10.1101/2021.04.16.21255616; this version posted April 18, 2021. The copyright holder for this preprint

(which was not certified by peer review) is the author/funder, who has granted medRxiv a license to display the preprint in perpetuity.

It is made available under a CC-BY-NC-ND 4.0 International license .

childcare facilities. In 8 out of 14 childcare facilities $(57.1 \%)$ none or only isolated cases without possible epidemiological association occurred. In 3 out of $14(21.4 \%)$ there was a maximum of 2 SARS-CoV-2 infections with a possible epidemiological link while in 3 out of 14 facilities (21.4\%) there were outbreaks involving at least 3 (3-10) cases. In all outbreaks positive stool samples in children could be detected (figure 2).

7/9 children with undetected SARS-CoV-2 infection attended their childcare facilities during viral shedding. In 3 cases we could detect none or maximal one possibly linked case. 4 cases were linked to outbreaks in two different childcare facilities. Given the retrospective study design, we cannot make assumptions about the index case of the outbreaks though.

\section{Quarantine}

Eleven of the 14 participating childcare facilities had at least one episode of mandated quarantine by the local health department due to a PCR-confirmed SARS-CoV-2 infection at their institution. In one of the childcare facilities with an ordered quarantine episode we could not detect any positive stool sample or seropositive adults. At all 3 institutions with detected outbreaks quarantine was ordered accordingly. In 2 of the remaining 3 childcare facilities without quarantine episodes we detected a total of 3 SARS-CoV2-positive stool samples with part of the children attending their childcare facility during time of stool viral shedding. In all three childcare facilities without quarantine episodes, we could only detect isolated cases of SARS-CoV-2 with no epidemiological link.

\section{Discussion:}

The rate of seropositive participants during the low-prevalence phase following the first wave in the Federal State of Saxony/Germany was very low, with only 2 detected cases. Both of 
these participants previously knew of their infections, quarantine warranties were issued accordingly, and we could not find connected cases to either participant. This supports the assumption that the current testing and quarantine methods in Germany during a lowprevalence phase were effective and could successfully prevent an undetected spread of SARS-CoV-2. In accordance, we could only find evidence for one undetected infection in a child during this period. Even though this child visited the childcare facility and no special hygiene or distancing measures were taken neither by the parents nor by the childcare workers, we did not detect a secondary case.

The increasing SARS-CoV-2 cases during the second wave in the general population was mirrored in our study population. While the rate of seropositive participants rose considerably by January 2021, this increase was proportional to the increase within the general population in Dresden, Germany. The number of undetected infections detected only by antibody testing continued to be lower than previously assumed by some authors. (DOI:

10.1126/science.abb3221).We could not detect a significant difference between the rate of seropositive parents and childcare workers. The percentage of SARS-CoV-2 positive children within the high-prevalence study phase was considerably lower than the rate of seropositive adults. This finding is supported by previous studies that also reported lower infection rates in children $^{5,12}$.

Over the whole study period, we detected a maximum of three connected cases in children, further strengthening the hypothesis that childcare facilities are not a major source of uncontrolled clusters ${ }^{13}$. Noteworthy as well was the fact that in two cases an infection among siblings was detected, in both cases the other sibling did not test positive in the corresponding stool samples.

About $50 \%$ of SARS-CoV-2 infections in children could not be connected to a secondary case within our study population. 
medRxiv preprint doi: https://doi.org/10.1101/2021.04.16.21255616; this version posted April 18, 2021. The copyright holder for this preprint

While the rate of participating children only amounted to approximately $20 \%$, we included an average of $72 \%$ of childcare workers. Due to this high participation rate, we are confident to have a reliable amount of samples analysed to evaluate the rate of SARS-CoV-2 infections among this group. We could not detect a significantly larger rate of infected childcare workers compared to the participating parents. While parents were significantly more often seropositive when their children visited the childcare facility during the lockdown period, this also implies a working environment without the possibility of home-office. This effect could therefore also be owed to the larger number of regular contacts within the work environment outside the household. This assumption is supported by the lower percentage of SARS-CoV-2 positive children in emergency care compared to those who stayed at home during the strict lockdown.

The percentage of seropositive childcare workers whose infection was possibly connected to their childcare facility was considerably higher than among seropositive parents. Considering the fact that there was a significantly higher rate of seropositive childcare workers with mainly administrative duties compared to those without, the higher infection rate in childcare workers compared to children as well as the extremely limited spread linked to undetected SARS-CoV-2 positive children suggests that transmission between adults within the childcare facilities occurs more frequently than between children and adults. Therefore, hygiene and distancing measures between childcare workers themselves might be the key measures in these institutions and more important than between children and workers.

There are several limitations to our study. We enrolled a limited number of participants in our study, thus it was possible that infections remained undetected. Moreover, a lower sensitivity of PCR-testing for SARS-CoV-2 in stool samples than in oro- and nasopharyngeal swaps might also contribute to underestimating the true numbers of infections ${ }^{14}$. 
However, the inclusion of low- as well as high-prevalence settings within the study period and the high participation rate of childcare workers in all facilities are strengths of our study. Additionally, the use of antibody testing instead of PCR testing reduces the possibility of missed undetected SARS-CoV-2 cases at least in parents and childcare workers.

\section{Conclusion}

The study could not provide evidence for a relevant asymptomatic ("silent") spread of SARS-

CoV-2 in childcare facilities, despite the lack of hygiene or distancing measures in this age

group. In addition, adults seem to transmit SARS-CoV-2 more frequently than children. These

findings add to the evidence that childcare and educational settings do not play a crucial role in driving the SARS-CoV-2 pandemic. 
medRxiv preprint doi: https://doi.org/10.1101/2021.04.16.21255616; this version posted April 18, 2021. The copyright holder for this preprint (which was not certified by peer review) is the author/funder, who has granted medRxiv a license to display the preprint in perpetuity.

\section{Acknowledgements:}

We thank R. Fischer for excellent technical support.

\section{References:}

1. Zhu N, Zhang D, Wang W, et al. A Novel Coronavirus from Patients with Pneumonia in China, 2019. N Engl J Med. 2020;382(8):727-733. doi:10.1056/nejmoa2001017

2. Cowling BJ, Ali ST, Ng TWY, et al. Impact assessment of non-pharmaceutical interventions against coronavirus disease 2019 and influenza in Hong Kong: an observational study. Lancet Public Heal. 2020;5(5):e279-e288. doi:10.1016/S24682667(20)30090-6

3. Bialek S, Gierke R, Hughes M, McNamara LA, Pilishvili T, Skoff T. Coronavirus Disease 2019 in Children - United States, February 12-April 2, 2020. MMWR Morb Mortal Wkly Rep. 2020;69(14):422-426. doi:10.15585/mmwr.mm6914e4

4. Armann JP, Diffloth N, Simon A, et al. Hospital admission in children and adolescents with covid-19 early results from a national survey conducted by the German society for pediatric infectious diseases (DGPI). Dtsch Arztebl Int. 2020;117(21):373-374. doi:10.3238/arztebl.2020.0373

5. Gudbjartsson DF, Helgason A, Jonsson H, et al. Spread of SARS-CoV-2 in the Icelandic Population. N Engl J Med. 2020;382(24):2302-2315. doi:10.1056/nejmoa2006100

6. Loades ME, Chatburn E, Higson-Sweeney N, et al. Rapid Systematic Review: The Impact of Social Isolation and Loneliness on the Mental Health of Children and Adolescents in the Context of COVID-19. J Am Acad Child Adolesc Psychiatry. 2020;59(11):1218-1239.e3. doi:10.1016/j.jaac.2020.05.009

7. Ludvigsson JF. Systematic review of COVID-19 in children shows milder cases and a better prognosis than adults. Acta Paediatr Int J Paediatr. 2020;109(6):1088-1095. doi:10.1111/apa.15270

8. Brandal LT, Ofitserova TS, Meijerink H, et al. Minimal transmission of SARS-CoV-2 from paediatric COVID-19 cases in primary schools, Norway, August to November 2020. Eurosurveillance. 2020;26(1). doi:10.2807/1560-7917.ES.2020.26.1.2002011

9. Ismail SA, Saliba V, Lopez Bernal J, Ramsay ME, Ladhani SN. SARS-CoV-2 infection and transmission in educational settings: a prospective, cross-sectional analysis of infection clusters and outbreaks in England. Lancet Infect Dis. Published online 2020. doi:10.1016/S1473-3099(20)30882-3

10. Wölfel R, Corman VM, Guggemos W, et al. Virological assessment of hospitalized patients with COVID-2019. Nature. 2020;581(7809):465-469. doi:10.1038/s41586020-2196-x

11. Chen Y, Chen L, Deng Q, et al. The presence of SARS-CoV-2 RNA in the feces of COVID-19 patients. J Med Virol. Published online 2020. doi:10.1002/jmv.25825

12. Stringhini S, Wisniak A, Piumatti G, et al. Seroprevalence of anti-SARS-CoV-2 IgG antibodies in Geneva, Switzerland (SEROCoV-POP): a population-based study. Lancet. 2020;396(10247):313-319. doi:10.1016/S0140-6736(20)31304-0 
medRxiv preprint doi: https://doi.org/10.1101/2021.04.16.21255616; this version posted April 18, 2021. The copyright holder for this preprint

(which was not certified by peer review) is the author/funder, who has granted medRxiv a license to display the preprint in perpetuity.

It is made available under a CC-BY-NC-ND 4.0 International license .

13. Macartney K, Quinn HE, Pillsbury AJ, et al. Transmission of SARS-CoV-2 in Australian educational settings: a prospective cohort study. Lancet Child Adolesc Heal. 2020;4(11):807-816. doi:10.1016/S2352-4642(20)30251-0

14. Wu Y, Guo C, Tang L, et al. Prolonged presence of SARS-CoV-2 viral RNA in faecal samples. Lancet Gastroenterol Hepatol. Published online 2020. doi:10.1016/S24681253(20)30083-2

15. Stadt Dresden. Corona-Dashboard Dresden. https://experience.arcgis.com/experience/d2386f3214c1451c81b242be69bb3d50

Figure 1: Timeline of serological testing (1: baseline, 2: $2^{\text {nd }}$ serological testing, $3: 3^{\text {rd }}$ serological testing, 4: additional serological testing in December 2020) and reported numbers of SARS-CoV-2 infections in Dresden, Saxony/Germany ${ }^{15}$

Figure 2: Positive SARS-CoV-2 infected children and the occurrence of epidemiological linked transmissions within the single participating childcare facilities (green - no epidemiological link detected, yellow - single cases without epidemiological link detected, orange -2 epidemiologically linked cases detected, red - outbreaks with $>2$ epidemiologically linked cases detected, stopwatch - officially mandated quarantine by local health department during study period) 
medRxiv preprint doi: https://doi.org/10.1101/2021.04.16.21255616; this version posted April 18, 2021. The copyright holder for this preprint (which was not certified by peer review) is the author/funder, who has granted medRxiv a license to display the preprint in perpetuity.

It is made available under a CC-BY-NC-ND 4.0 International license .

Table 1: Participants during low- and high-prevalence phase

\begin{tabular}{|l|c|c|c|}
\cline { 2 - 4 } \multicolumn{1}{c|}{} & Baseline & $\begin{array}{c}\text { Low-prevalence } \\
\text { Phase }\end{array}$ & $\begin{array}{c}\text { High-prevalence } \\
\text { Phase }\end{array}$ \\
\hline Parents (n) & & 243 & 236 \\
\hline $\begin{array}{l}\text { Childcare workers } \\
(\mathbf{n})\end{array}$ & & 200 & 187 \\
\hline Children (n) & & 232 & 222 \\
\hline
\end{tabular}

Table 2: Baseline Demographic Data; IQR: Interquartile Range

\begin{tabular}{|l|c|c|c|}
\cline { 2 - 4 } \multicolumn{1}{c|}{} & \multicolumn{1}{c|}{$\begin{array}{c}\text { Childcare } \\
\text { workers }\end{array}$} & Parents & Children \\
\hline Number of participants & 233 & 299 & 318 \\
\hline Age, median (IQR) & $39(32-49)$ & $37(32-40)$ & $4(2-5)$ \\
\hline Sex - female, \% & 88.2 & 68.2 & 49.5 \\
\hline $\begin{array}{l}\text { Household size, median } \\
\text { (IQR) }\end{array}$ & $3(2-3)$ & & $4(3-4)$ \\
\hline
\end{tabular}

Table 3: Seropositive adult study-participants and SARS-CoV-2 positive children during lowand high-prevalence phase

\begin{tabular}{|l|c|c|}
\cline { 2 - 3 } \multicolumn{1}{c|}{} & \multicolumn{1}{c|}{$\begin{array}{c}\text { Low-prevalence } \\
\text { Phase }\end{array}$} & $\begin{array}{c}\text { High-prevalence } \\
\text { Phase }\end{array}$ \\
\hline $\begin{array}{l}\text { All seropositive } \\
\text { participants }\end{array}$ & $2 / 443(0.5 \%)$ & $48 / 424(11.3 \%)$ \\
\hline Seropositive parents & $1 / 243(0.4 \%)$ & $25 / 236(10.6 \%)$ \\
\hline $\begin{array}{l}\text { Seropositive childcare } \\
\text { workers }\end{array}$ & $1 / 200(0.5 \%)$ & $23 / 187(12.3 \%)$ \\
\hline & $2 / 232(0.9 \%)$ & $15 / 222(6.8 \%)$ \\
\hline $\begin{array}{l}\text { SARS-CoV-2 positive } \\
\text { children }\end{array}$ & \multicolumn{2}{|c|}{} \\
\hline
\end{tabular}


$1^{\text {st }}$ July $2020-31^{\text {st }}$ January 2021

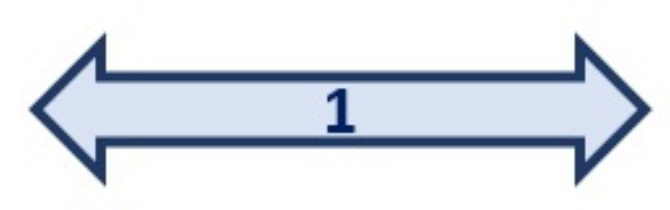


CHILDCARE FACILITY

다 1

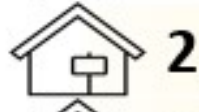

도 3

무 4

도 5

두 6

두 7

다 8

두 9

官 10

官 11

다 12

穴 13

다 14
SARS-CoV-2

POSITIVE CHILDREN
ORDERED QUARANTINE

YES

YES (6)

YES

NO

YES

NO

NO

YES

YES

YES

勒-

YES

-

YES

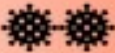

